\title{
Teacher Preparation for Effective Management of Early Childhood Schools in Nigeria
}

\author{
Florence Nkechi Okeke \\ Department of Educational Foundations and Administration \\ Faculty of Education, \\ Imo State University \\ Owerri, Nigeria
}

\begin{abstract}
Teachers are important factor in quality education and therefore should be properly prepared and managed. The success of programs in early childhood education is contingent up the availability of personnel trained to meet the individual needs of children. This paper examines teacher preparation for effective management of early childhood schools in Nigeria as a requisite for effective management. This implies training and retraining of professionals in the area. The paucity of universities in Nigeria that offer this discipline in their programme were listed. Conclusion was drawn and recommendations made which include amongst others that specialists in early childhood education should be in charge of the training and retraining of teachers.
\end{abstract}

\section{Introduction}

The need for high-quality childcare options is growing rapidly in response to changes in work and family patterns (Early \& Winton [3]). Advocates of developmentally appropriate early childhood education are increasingly interested in promoting inclusive programs of early education and care of both typically-developing children and children with disabilities. The success of such programs is contingent upon the availability of personnel trained to meet the individual needs of children with a wide range of abilities (Kemple, Hartle, Cornea \& Fox [8]). Teacher preparation is the process of initiating, preparing student-teachers; retraining of existing teachers in schools; and equipping them with relevant experience, skills and competences to tackle the responsibilities of educational profession effectively (Dashe [3], Nwite [10]). Teacher preparing if accomplished will develop capacity building and keep the teachers abreast with latest teaching skills and ready to interact with children and students in the classroom. There is currently scarcity of teachers who are adequately prepared to meet the challenges of handling early childhood schools.
In an effort to provide high-quality preschool education, policy makers are increasingly requiring public preschool teachers to have at least a Bachelor's degree, preferably in early childhood education (Early, Maxwell, Buchinal, Alva, Bender, Bryant etc,[4]). Policies focused on increasing teachers' education, improve classroom quality and maximizes children's academic gains are needed. In addition, raising the effectiveness of early childhood education requires a broad range of professional development activities and supports targeted toward teachers' interactions with children.

Education is the right of every child, therefore no child should be denied of it for any reason. This is in agreement with the assertion of the World Summit on the state of global Education for All Programme (EFA). Ajayi [1] stated that Nigeria has pledged its commitment to this, with the inauguration of the policy on early childhood education.

Early childhood or pre-primary education "is the education given in an educational institution to children prior to their entering the primary school. It includes the crèche/Daycare, the nursery and kindergarten" (FRN,[7]). In crèche/Daycare centres children from 0-3 years are taking care of, especially for working mothers and parents. The age bracket of children exposed to nursery and kindergarten is three to five years. There is no gainsaying the fact that management of this precious level of education and schools must be taking seriously. Management implies an orderly way of thinking. It describes in operator terms what is to be done, how it is to be done and how we know when it has been done (Varsha, [14]). Management is not a mystique but rather a method of operation. It is a judicious use of means to accomplish an end.

Education management is the theory and practice of the organization and administration of existing educational establishments and systems. School management, as a body of educational doctrines, comprises a number of principles and precepts relating primarily to the technique of classroom procedure and derives largely from the practice of successful teachers. Paul [13] maintained that educational management is a comprehensive effort dealing with the educational practices. It is a 
dynamic side of education. It deals with educational institutions-right from the schools and colleges to the secretariat and in relation to early childhood schools. It is concerned with both human and material resources. The human elements include (i) children (ii) parents, (iii) teachers and (iv) other employees in general. On the material side there are (a) finance (b) buildings and grounds, (c) equipments and instructional supplies. Besides, there are ideas, laws and regulations and so on, having a bearing on the educational process. The blending of these 'parts' into a 'whole' is educational management. The purpose of educational management is to bring pupils and teachers under such conditions as will more successfully promote the end of education. Whose responsibility it is to harness these resources? The teacher, that why it is imperative that teachers should be specially trained if early childhood schools will be properly managed. Okeke[12] studied Policy Gaps and Management of Early Childhood Education in Nigeria. It is to fill the gap on teacher preparation for effective management of early childhood schools in Nigeria that constitutes the problem of this work.

\section{Teacher Preparation as a Requisite for Effective Management of Early Childhood Schools}

It is clearly stated that "no educational system can rise above the level of its teachers" (FRN,[7]). The above statement is supported by (Ajayi[1]), identifying the fact that laudable educational initiatives have collapsed previously simply because of "teacher factor" which was not taken seriously.

Government's pronouncement that to ensure the success of Universal Basic Education (UBE) early childhood education inclusive, teacher issues would be taken into consideration, especially in the area of raising the level of teachers' general education. The National Policy on Education (FRN,[7]) states that it is "the responsibilities of government for preprimary education to promote the training of qualified pre-primary teachers in adequate number etc. Okeke [12] found out in a study that this policy is on paper but never implemented which results in mushroom nursery schools and daycare centres.

Be that as it may, there must be a solution to a problem. Therefore in a bid to answer eight questions on teacher preparation by (Allen[2]), some special approaches to prepare teachers to face the tasks of early childhood schools is established. The questions include: (a) How does subject knowledge contribute to teacher effectiveness? (b) How does pedagogical coursework contribute to teacher effectiveness? (c) The extent to which high quality field experience prior to certification contributes to teacher effectiveness, accreditation of teacher preparation programs etc? From the foregoing questions and expectations of teacher education and preparation provisions to meet the different levels of education is imperative for the achievement of high standard in early childhood schools.

Suffice it to state that the necessity for teacher preparation and management should be viewed as a serious and sacred duty that must never be toyed with, if teaching much fulfills its divine professional mandate which is cultivating generations of highly responsible, disciplined and useful Nigerians. Ogah [11] maintained that the teacher is without controversy, the fulcrum upon which the planned curriculum implementation revolves. The teacher preparation for the pre-primary affects the primary school level and even the secondary. So if preprimary school teachers are properly trained and they do their professional duties creditably, the products of the pre-primary schools will be of high quality. Those that will be handed over to the primary school are bound to be qualitative and so on. The reverse is the case if poor preparation of teachers is done at the pre-primary level, the bad effect will be transferred step by step to the highest level. Therefore, the recipes for effective teacher preparation include increased entry requirements, meaningful research work, continuous supervision of teachers, regular inservice training programmes and provision of sound infrastructures for effective instruction.

This special preparation of teachers will be very useful because Bush in (Ajayi [1]) stated that the years between birth and age five are the foundation upon which successful or otherwise lives are build and $85 \%$ (percent) of the brain is formed within the first five years of life which leads to greater performance in education. Hess and Croft as noted by (Maduewesi[9]) opine that children who through some special intervention, had pre-school programmes tend to be more positive about school, more out going and verbally assertive, more able to work independently and more comfortable in school situation. It would expose a controlled structured activities and the need for a lot of interactive learning by toys at this early childhood education. This study would expose the recipe and standard of this level of education to education managers and proprietors. It would be relevant if properly managed to the government, because a lot of funds will be generated from it. This study would lead to the improvement of policies for early childhood education. It will also expose the imperativeness of teacher preparation for early childhood education.

Looking at the numerous universities in the country, it is apparent that only very few institutions run early childhood education as a discipline at an undergraduate level, a postgraduate level, or on a part-time basis. Some of the ones identified that offer the programme include:

1. University of Ibadan, Ibadan 


\author{
2. University of Lagos, Lagos \\ 3. Lagos State University, Lagos \\ 4. University of Ado-Ekiti, Ado-Ekiti \\ 5. Adeukunle Ajasin University, Akungba \\ 6. Olebisi Onabanjo University, Ago-Iwoye \\ 7. Tai Solarin University of Education, Ijebu- \\ 8. University of Port-Harcourt, Port-Harcourt \\ 9. Ebonyi State University, Abakaliki. \\ 10. Obafemi Awolowo University, Ile-Ife \\ 11. University of Uyo - Uyo.
}

Ode

The percentage of institutions offering the course and the number of students taking up the course cannot satisfy the demand from the teeming population of over 12.73 million preschoolers in Nigeria (Basic Education and Trends in Nigeria, 1998).

In conclusion, teacher preparation is the foundation upon which successful educational institution at all levels hinges. Special interest should be developed in training teachers who will solidify this bedrock.

In recommendation, (i) teachers should be trained and retrained for effectiveness at this level. (ii) The activities should also be structured and well organized. (iii) The government should invest in the preparation of the early childhood teachers. (iv) Specialists in early childhood education should be in charge of the training and retraining of teachers. (v) More universities should be encouraged to develop programmes in early childhood and the society sensitized to pick interest in its study and management.

\section{References}

[1] Ajayi, H.O. (2008) Contemporary Issues on Early Childhood. 9( 4) COLLOQUIUM.

[2] Allen Michael (2003). Eight Questions on Teacher Preparation: What Does the Research Say? http://eric.ed.gov/PDFS/ED479051.pdf Retrieved 25-72012.

[3] Dashe, N.P. (2007) Teacher Preparation for Effective Implementation of the UBE programmes in Nigeria. Journal of Teacher Education, 4(3) 143-151.

[4] Early, D.M., Maxwell, K.L, Burchinal M., Alva, S., Bender, R.H., Bryant, D., Cai Clifford, R.M., Ebanks, C., Griffin, J.A., Henry G.T., Howes, C., Iriondo-P.J., Jeon H.J., Mashburn, A.J., Peisner-Feinberg, E., Pianta, R.C., Vandergrift, N. \& Zill, N. (2007). Teacher Education, Classroom Quality and Young Children's Academic Skills; Results from seven studies of Preschool Programs http://onlinelibrary.wiley.com/doi/10.1111/j.14678624.2007.01014.x/abstract Retrieved 17/7/2012.

[5] Early, D.M., Maxwell, K.L. Early Childhood Education in Nigeria: A Reality or A Mirage. http://www.wwwords.co.uk.pdf/validate.asp?j=ciec\&vol=9 \&issue $=4$ \&year $=2008 \&$ article=11Ajayi $\quad$ CIE 9 4web Retrieved 25/7/2012.

[6] Early, D.M. \& Winton, P.J. (2001). Preparing the Workforce: early childhood teacher preparation at 2-and-4year institutions of higher education. U.S.A.: Early Childhood Research Quarterly 16, 285-306.

[7] Federal Republic of Nigeria (2004). National Policy on Education. Lagos: NERDC Press.

[8] Kemple, K.M., Harthe, L.C., Correa, V.I. \& Fox Lise (2007). Preparing Teachers for Inclusive Education: The Development of a Unified Teacher Education Program in Early Childhood and Early Childhood Special Education. http://tes.sagepub.com/content/17/1/38.abstract Retrieved $17 / 7 / 2012$

[9] Maduewesi, E. (1996) The Vision and Mission of Preprimary and Primary Education. Paper presented at the National Conference organized by the NCCE at NTI Conference Centre, Kaduna.

[10] Nwite Onuma (2011). Teacher Preparation and Information and Communication Technology (ICT) in Ebonyi State University for the Challenges of 202020 In B.G. Nworgu and J.C. Buseri (Eds) Human Capacity Development for Vision 20-2020. Proceedings of the 25th Annual Congress of the Nigerian Academy of Education, Yenagoa, Baylesa State.

[11] Ogah, E.U. (2007). Teacher Preparation and Management for Quality Instruction in Secondary Schools. Nigerian Journal of Curriculum Studies 14 (1) 50-59.

[12] Okeke, F.N. (2011). Policy Gaps and Management of Early Childhood Education in Nigeria. Proceedings of London International Conference on Education (LICE) 114-119 www.infonomics society.org

[13] Paul Monroe (2011) Meaning of Educational Management.

http://ww.preservearticles.com/2011122018637/what-iseducational-management.html Retrieved 25/7/2012

[14] Varsha Sen (2011) What is Educational Management? http://ww.preservearticles.com/2011122018637/what-iseducational-management.html. Retrieved 25/7/2012. 